\title{
Yield attributes and yield of okra as influenced by cultivars at Sylhet region
}

\author{
S. R. Saha*, A. F. M. S. Islam, M. M. Hasan and M. M. Rob ${ }^{1}$ \\ Department of Crop Botany and Tea Production Technology, Sylhet Agricultural University, Sylhet-3100 and \\ ${ }^{1}$ Department of Horticulture, Sylhet Agricultural University, Sylhet-3100, 'E-mail: sushmi.sau@gmail.com.
}

\begin{abstract}
An experiment was conducted at the field laboratory of Sylhet Agricultural University from May to October 2013 comprising of 8 okra cultivars viz. BARI Dherosh-1 (control), Orka Onamika, Bankim, Durga, JO (Japanese okra)-1, JO-2, JO-3 and JO-4. This study was intended to select the superior okra cultivar(s) based on yield performance in acidic soil conditions. The experiment was laid out in a Randomized Complete Block Design (RCBD) with three replications and all the cultivars were evaluated in relation to yield and yield attributes. Significant variations were observed in almost all parameters. Results revealed that high yielding cultivars $\mathrm{JO}-3$ and Bankim produced largest fruits, however maximum number of fruits and fruit setting (\%) were exhibited by the latter. The cultivars JO-1 and JO-4 showed maximum fruit weight but JO-4 provided highest fruit diameter. The cultivars Bankim followed by JO-3 \& JO-4 were evaluated to be promising cultivars at Sylhet regions considering overall performances regarding yield and yield attributes.
\end{abstract}

Keywords: Okra cultivars, Flower production, Yield attributes, Sylhet Region

\section{Introduction}

Okra (Abelmoschus esculentus L.) is widely grown throughout the tropics (Purseglove, 1987) belongs to family malvaceae and originated from tropical Africa or Asia. It is considered as one of the popular summer vegetables in Bangladesh. Young aged okra can be used as salads and for its delicious taste and it is also consumed in different manners such as soups and stews, fresh or dried, fried or boiled (Ndunguru and Rajabu, 2004). The okra fruits are rich in vitamins, calcium, potassium and other minerals including iodine (IBPGR, 1990; Lee et al., 2000). Okra has medicinal value as well (Rashid, 1993). Its medicinal value has also been reported in curing ulcers and relief from hemorrhoids (Adams, 1975). Total production of okra was about 44000 metric tons from 26000 acres of land in Bangladesh with an average yield of nearly $4.6 \mathrm{t} \mathrm{ha}^{-1}$ in the year 2012-2013 (BBS, 2013), which is much lower in compare with the yield ranges from 7-12 $\mathrm{t} \mathrm{ha}^{-1}$ in the developed countries (Yamaguchi, 1998). For the multidimensional impacts of okra it is mandatory to think how the production of okra could be increased by selecting suitable cultivar(s).

Sylhet is one of the special AEZs of Bangladesh due to its soil characters including acidity. Soil pH of the regions ranges from 4.5 to 6.5. Plants grown in acidic soil differs in nutrient uptake than normal soil. The total production of okra in Sylhet District is only about 1904 metric tons (Anonymous, 2012) from 272 ha of land. The production is too low to meet up the demand and some well suited variety need to be selected for this region to increase the production. So the present piece of research work was conducted to evaluate the cultivars performance based on yield and yield attributes of okra with a view to selecting suitable one(s).

\section{Materials and Methods}

The study was conducted at the field laboratory of Sylhet Agricultural University from May to October 2013. The experimental soil belongs to the AEZ-20: Eastern Surma Kushiyara Floodplain. Soil is clay loam type with characterized by acidic $(\mathrm{pH} \mathrm{4.83)}$ in nature. The experimental region is characterized by heavy rainfall and high temperature during Kharif season with profound sunshine and cloudy weather. Eight cultivars of Okra (Japanese Okra: JO-1, JO-2, JO-3, \& JO-4, Indian okra: Bankim, Durga, Orka Onamika and a local check cultivar (BARI Dherosh-1) were used as experimental materials. The experiment was laid out in a Randomized Complete Block Design (RCBD) with three replications. Eight Treatments (Eight cultivars) were randomly allotted in each replication. The total number of plots was 24 . The size of the plot was $2.3 \mathrm{~m} \times 1.2 \mathrm{~m}$. The adjacent blocks and neighbouring plots were separated by 
$0.70 \mathrm{~m}$ and $0.50 \mathrm{~m}$, respectively. Okra seeds were sown in lines with a spacing of $0.50 \mathrm{~m}$ and $0.45 \mathrm{~m}$ for row to row and plant to plant, respectively. Cowdung, urea, triple super phosphate, muriate of potash were applied to the plots for okra cultivation at the rate of $3000,150,100$ and $150 \mathrm{~kg} \mathrm{ha}^{-1}$ respectively (BARC, 2005). Total amount of cowdung, triple super phosphate, muriate of potash and one third of urea were applied as basal dose during the final land preparation. Remaining urea was applied in two installments as top dressing at 25 days after sowing (DAS) and 40 DAS (days after sowing). The seeds were soaked overnight in the water prior to sowing. Two to three seeds were sown in each pit on 15 May 2013 in the rows. Seven days after germination the weaker seedlings were removed keeping the healthier one in each pit to grow properly. Weeding was done 4 times to keep the plots free from weeds and the soil was mulched by breaking the soil crust for easy aeration and conservation of soil moisture. The plots were watered four times at regular interval during the growth season to keep the field moist for better growth and development of plant. Each node bears a leaf and flower emerges axillary. Different coloured woolen threads were loosely fastened in leaf petioles to record total number of flowers. It was observed that ovary of some flowers aborted in the very next day after emergence. By deducting the aborted fruits, total number of developed fruits were recorded. Data on yield and yield attributes such as days to first flowering, total number of flowers plant ${ }^{-1}$, aborted fruits plant $^{-1}$, total number of fruits plant ${ }^{-1},(\%)$ fruit setting, fruit size $(\mathrm{cm})$, individual fruit fresh weight $(\mathrm{g})$, number of seeds fruit ${ }^{-1}, 100$-seed weight $(\mathrm{g})$, yield (g) plant ${ }^{-1}$ and yield $\left(\mathrm{t} \mathrm{ha}{ }^{-1}\right.$ ) were collected. The data were subjected to analysis of variance (ANOVA) using the MSTAT-C (Russel, 1986) software and the means were separated according to Duncan's Multiple Range Test (DMRT).

\section{Results \& Discussion}

Days to first flowering: The number of days required for first flowering is one of the important inherent characters which indicates the earliness of the cultivars. The cultivar Bankim produced early flower (35.33 days) which was statistically similar to the other cultivars $\mathrm{JO}-1, \mathrm{JO}-2$ and Orka Onamika (average of 37.22 days) and the cultivar JO-3 showed delayed flowering (53.67 days) among the cultivars (Table 1). Saifullah et al. (2009), Islam et al. (2000) observed the similar variation in case of days to first flowering.

Table 1. Days to first flowering, total no. of flowers plant ${ }^{-1}$, aborted fruits plant ${ }^{-1}$, total no. of fruits plant ${ }^{-1}$, and fruit setting (\%) of different okra cultivars

\begin{tabular}{lccccc}
\hline \multicolumn{1}{c}{ Cultivars } & $\begin{array}{c}\text { Days to first } \\
\text { flowering }\end{array}$ & $\begin{array}{c}\text { No. of flowers } \\
\text { plant }^{-1}\end{array}$ & $\begin{array}{c}\text { No. of fruits } \\
\text { plant }^{-1}\end{array}$ & $\begin{array}{c}\text { Aborted fruits } \\
\text { plant }^{-1} \text { (no.) }\end{array}$ & $\begin{array}{c}\text { Fruit setting } \\
\text { (\%) }\end{array}$ \\
\hline BARI dherosh-1 & $40.00 \mathrm{c}$ & 58.67 & $32.87 \mathrm{ab}$ & 25.80 & $56.20 \mathrm{~b}$ \\
Orka Onamika & $37.33 \mathrm{~d}$ & 44.43 & $28.87 \mathrm{ab}$ & 15.53 & $66.70 \mathrm{a}$ \\
Bankim & $35.33 \mathrm{~d}$ & 57.80 & $41.13 \mathrm{a}$ & 16.63 & $69.48 \mathrm{a}$ \\
Durga & $43.67 \mathrm{~b}$ & 41.53 & $29.0 \mathrm{ab}$ & 12.57 & $68.65 \mathrm{a}$ \\
JO-1 & $37.33 \mathrm{~d}$ & 34.57 & $18.9 \mathrm{bc}$ & 14.57 & $54.04 \mathrm{~b}$ \\
JO-2 & $37.00 \mathrm{~d}$ & 28.67 & $14.1 \mathrm{c}$ & 14.57 & $48.74 \mathrm{~b}$ \\
JO-3 & $53.67 \mathrm{a}$ & 37.00 & $18.43 \mathrm{bc}$ & 18.53 & $49.17 \mathrm{~b}$ \\
JO-4 & $43.33 \mathrm{~b}$ & 51.20 & $28.87 \mathrm{ab}$ & 22.33 & $56.07 \mathrm{~b}$ \\
\hline CV (\%) & $3.04 \%$ & 27.74 & 31.47 & 28.75 & 8.93 \\
\hline Significance level & $* *$ & $\mathrm{NS}$ & $*$ & $\mathrm{NS}$ & $*$ \\
\hline
\end{tabular}

Treatments bearing similar letter are statistically similar at $5 \%$ level of probability according to DMRT.

${ }^{* *}=$ Significant at $1 \%$ level of probability, ${ }^{*}=$ Significant at $5 \%$ level of probability, NS= Non significant.

Flowers no. plant $^{-1}$

Cultivars effect was insignificant regarding flowers number plant ${ }^{-1}$. The highest number of flower (58.67) was recorded in the cultivar BARI Dherosh-1 and the lowest number of flower (28.67) was found in JO-1 (Table 1). lyagba et al. (2012) reported the number of flowers ranges from 11.6-13.7 and 10.6-12.8 in two consecutive years.

Aborted fruits plant $^{-1}$

Results showed that the eight cultivars responded insignificantly regarding total no. of aborted fruits plant $^{-1}$ (Table 1). Minimum aborted fruits (12.57) was recorded in Durga whereas BARI Dherosh-1 aborted maximum fruits (25.80). lyagba et al. (2012) observed the variation in case of number of fruits abortion within the range from 1.8-2.4. 
Fruits no. plant $^{-1}$

Number of fruits plant ${ }^{-1}$ was significant among the cultivars (Table 1). Bankim produced the maximum number of fruits (41.13) plant ${ }^{-1}$. On the contrary, the minimum number of fruits (14.1) plant ${ }^{-1}$ was found in JO-2. Variation in number of fruits plant ${ }^{-1}$ (5.30 to 33.30) was also recorded in the findings of Saifullah et al. (2009).

\section{Fruit setting}

Fruit bearing capacity i.e. fruit setting was significantly affected among the studied cultivars. Highest fruit setting was found in Bankim (69.48\%). In JO-2 and JO-3 fruit set was only about $50 \%$ (Table 1). Increased percent fruit setting might be due to higher concentration of $\mathrm{GA}_{3}$ (Katung et al. 2007).

\section{Fruit size}

Fruit length and diameter varied significantly among the studied cultivars (Table 2). Longest fruit length $(15.55 \mathrm{~cm})$ was noted in Durga, while the shortest found in JO-2 $(12.28 \mathrm{~cm})$. Variation in fruit length among different genotypes of okra was also recorded by Islam (1997); Halim (2008); Prakash et al. (2001) and Saifullah et al. (2009). The highest fruit diameter $(1.67 \mathrm{~cm})$ was found in JO-4 and the lowest $(1.20 \mathrm{~cm}$ ) found in Durga (Table 3). Islam (1997) and Saifullah et al. (2009) also concluded significant variation regarding fruit diameter in different genotypes of okra.

Table 2. Cultivars response on yield attributes and yield of okra

\begin{tabular}{|c|c|c|c|c|c|c|c|}
\hline Cultivars & $\begin{array}{l}\text { Fruit length } \\
(\mathrm{cm})\end{array}$ & $\begin{array}{l}\text { Fruit diameter } \\
(\mathrm{cm})\end{array}$ & $\begin{array}{l}\text { Individual fruit } \\
\text { fresh wt. (g) }\end{array}$ & $\begin{array}{l}\text { Number of } \\
\text { seeds fruit }\end{array}$ & $\begin{array}{l}\text { 100-seed } \\
\text { weight }(\mathrm{g})\end{array}$ & $\begin{array}{l}\text { Yield (g) } \\
\text { plant }^{-1}\end{array}$ & $\begin{array}{c}\text { Yield } \\
\left(\mathrm{t} \mathrm{ha}^{-1}\right)\end{array}$ \\
\hline BARI dherosh-1 & $13.77 \mathrm{~b}$ & $1.33 d$ & $18.99 \mathrm{~d}$ & $66.38 a$ & $6.62 a$ & $320.0 \mathrm{c}$ & $9.280 \mathrm{c}$ \\
\hline Orka Onamika & $13.52 b$ & $1.40 \mathrm{~d}$ & $19.24 d$ & $53.17 d$ & $6.39 \mathrm{~b}$ & $323.3 \mathrm{bc}$ & $9.377 \mathrm{bc}$ \\
\hline Bankim & $15.41 \mathrm{a}$ & $1.37 \mathrm{~cd}$ & $22.42 \mathrm{~b}$ & $57.95 \mathrm{bcd}$ & $6.53 \mathrm{ab}$ & $433.3 \mathrm{a}$ & $12.56 a$ \\
\hline Durga & $15.55 a$ & $1.20 \mathrm{e}$ & $22.81 \mathrm{~b}$ & $55.21 \mathrm{~cd}$ & $6.22 \mathrm{c}$ & 326.7 bc & $9.470 \mathrm{bc}$ \\
\hline $\mathrm{JO}-1$ & $12.98 \mathrm{bc}$ & $1.57 b$ & $24.41 \mathrm{a}$ & $67.00 \mathrm{a}$ & $5.82 e$ & $400.0 \mathrm{a}$ & $11.59 a$ \\
\hline JO-2 & $12.28 \mathrm{c}$ & 1.60ab & $20.97 c$ & $63.59 \mathrm{ab}$ & $6.01 \mathrm{~d}$ & $356.7 \mathrm{~b}$ & $10.34 b$ \\
\hline JO-3 & $15.14 a$ & $1.43 c$ & $22.68 b$ & $61.9 \mathrm{ab}$ & $4.77 \mathrm{~g}$ & $406.7 \mathrm{a}$ & $11.78 a$ \\
\hline $\mathrm{JO}-4$ & $13.08 \mathrm{bc}$ & $1.67 a$ & $22.75 a$ & $61.50 \mathrm{abc}$ & $5.64 f$ & 340.0 bc & $9.857 \mathrm{bc}$ \\
\hline CV (\%) & 4.43 & 3.33 & 2.42 & 6.22 & 1.49 & 5.29 & 5.27 \\
\hline Sig. level & ** & ** & $* *$ & ** & ** & ** & ** \\
\hline
\end{tabular}

Cultivar(s) bearing similar letter are statistically similar as $5 \%$ level of probability according to DMRT.

$* *=$ Significant at $1 \%$ level of probability.

\section{Individual fruit fresh weight}

Single fruit weight was statistically significant and ranged from 18.99 to $24.40 \mathrm{~g}$ (Table 2). The highest fruit weight $(24.40 \mathrm{~g})$ was recorded in the cultivar JO-1 and the lowest fruit weight $(18.99 \mathrm{~g})$ was found in BARI Dherosh-1. This variation in individual fruit weight may be due to the genetic potentiality of eight okra cultivars. This result is in agreement with the findings of Saifullah et al. (2009) and Islam et al. (2000) who showed variation in individual fruit weight of okra.

\section{Number of seeds fruit $^{-1}$}

The cultivars varied significantly regarding number of seeds fruit $^{-1}$ (Table 2 ). The maximum seed number (67.00) recorded in JO-1 which was statistically similar to the cultivar BARI Dherosh-1 (66.38) and the minimum seeds (53.17) obtained from Orka Onamika. The variation in the number of seeds fruit ${ }^{-1}$ depends $^{-1}$ on the genetic potential (Dash and Mishra, 1995). Variation in no. of seeds fruit ${ }^{-1}$ was also concluded by Saifullah et al., (2009), Halim (2008) and Islam (1997).

\section{0-seed weight}

Effect of 100 seed weight was significant among the cultivars (Table 2) and it varied from 4.77 to $6.62 \mathrm{~g}$. The heaviest seeds $(6.62 \mathrm{~g})$ were found in BARI Dherosh-1 which was statistically similar with Bankim $(6.53 \mathrm{~g})$. The lightest seeds $(4.77 \mathrm{~g})$ were recorded from JO-3. Variation in the 100 seed weight was genetically controlled characters and may be affected by the availability of food materials in the initially formed fruits. Similar variation was observed by Saifullah et al., (2009) where weight of 100 seeds ranged from 5.50 to $8.25 \mathrm{~g}$. 


\section{Yield plant $^{-1}$}

Fruit yield plant $^{-1}$ varied significantly among the cultivars (Table 2). The highest yield $(433.3 \mathrm{~g})$ was recorded in Bankim and lowest $(320 \mathrm{~g})$ found in BARI Dherosh-1 $(9.280 \mathrm{~g})$ which was similar to Orka Onamika (323.3 g). Variation in yield plant ${ }^{-1}$ was also reported by Saifullah et al. (2009) and Islam (2000).

\section{Yield}

The yield is the result of complex interaction of the parameter like no. of fruit, fruit setting (\%) and individual fruit weight. The highest yield $\left(12.56 \mathrm{t} \mathrm{ha}^{-1}\right)$ was obtained from cultivar Bankim because of maximum no. of fruit (41.13) and \% fruit setting (71.2) and the lowest $\left(9.28 \mathrm{t} \mathrm{ha}^{-1}\right.$ ) recorded in BARI Dherosh-1 (Fig. 1). Saifullah et al. (2009) showed variation in fruit yield which ranged from 2.76 to 19.24 t/ha among 121 genotypes. Islam et al. (2000) also reported regarding the variation in fruit yield.

The study revealed that a wide range of variability exists among the collected cultivars in respect of yield and yield contributing characters. In future breeding programme of okra could be performed based on these variabilities to develop a high yielding variety of okra with good quality in our country. These investigations suggest that the cultivars Bankim followed by JO-3 and JO-4 were very promising for better yield at Sylhet region.

\section{References}

Adams, C.F. 1975. Nutritive value of American foods in common units. U.S. Department of Agriculture, Agric. Handbook, 425, p.29.

Anonymous. 2012. Status of horticultural crop production in Sylhet region. Paper presentation in the workshop on "Prospects of Horticultural crop production in Sylhet region", held on 17 November 2012, Sylhet Agricultural University, Sylhet.

BARC. 2005. Fertilizer Recommendation Guide. Bangladesh Agricultural Research Council. Farmgate, New Airport Road, Dhaka. p.119.

BBS (Bangladesh Bureau of Statistics). 2013. Year book of Agricultural statistics of Bangladesh. Government of the People's Republic of Bangladesh. p.41.

Dash, G.B. and Mishra, P.K. 1995. Variation and character association of fruit yield and its component characters in okra. Curr. Agril. Res. 8(3-4): 123-127.

Halim, M.A. 2008. Seed yield and seed quality of some okra [Abelmoschus esculentus (L.) Moench] cultivars. M.S Thesis. Dept. of Hort. Bangabandhu Sheikh Mujibur Rahman Agric. Uni., Salna, Gazipur. pp. 28-39.

International Board for Plant Genetic Resources (IBPGR). 1990. Report on International Workshop on okra Genetic resources held at the National bureau for Plant Genetic Resources, New Delhi, India.

Islam, M.S. 1997. Off season performance of okra for vegetable and seed production. M.S Thesis. Dept. of Hort. Bangabandhu Sheikh Mujibor Rahman Agric. Uni., Salna, Gazipur. pp.26-52.

Islam, M.S., Rahman, M.M. and Ali, M. 2000. Off season production of okra as affected by sowing time. Ann. Bangladesh Agric.10 (1): 105-112.

lyagba A.G., Onuegbu, B.A. and IBE, A.E. 2012. Growth and yield response of okra [Abelmoschus esculentus (L.) Moench] varieties to weed interference in South-Eastern Nigeria. Global J. Sci. Frontier Res. 12(7): 22-31.

Katung, M.D., Olarewaju, J.D. and Mohammed, S.G. 2007. Seasonal response of okra (Abelmoschus esculentus (L.) Moench) varieties to gibberellic acid. Adv. Hort. Sci. 21(1): 14-18.

Lee, K.H., Cho, C.Y., Yoon, S.T. and Park, S.K. 2000. The effect of nitrogen fertilizer, plant density and sowing date on the yield of okra. Korean Journal of Crop Science. 35(8): 179-183.

Ndunguru, J. and Rajabu, A. 2004. Effect of okra mosaic virus disease on the above-ground morphological yield components of okra in Tanzania. Scientia Horticulturae. 99: 225-235.

Prakash, M., Kannan, K., Kumar, J.S. and Ganesan, J. 2001. Studies on the genetics of certain quantitative characters with particular reference to seed production in okra. Ann. of Agric. Res. 22(1): 80-82.

Purseglove, J.W. (1987). Tropical Crops Dicotyledones. Longman Singapore Publishers (Pvt.) Ltd. p. 367.

Rashid, M.M. 1993. Sabji Biggan (in Bengali). Bangla Academy, Dhaka. p.466.

Russell, D.F. 1986. MSTAT-C package programme. Crop and Soil Science Department, Michigan State University, USA.

Saifullah, M. and Rabbani, M.G. 2009. Evaluation and characterization of okra [Abelmoschus esculentus (L.) Moench] genotypes. Saarc. J. Agric. 7(1): 92-99.

Yamaguchi, M. 1998. World Vegetables-Principles, Production and Nutritive Values. Van Nasfirand Reinhoid. New York, USA. p.415. 